\title{
Revisiting the Issue of Theories of Integration Processes
}

\author{
Falkovich E. \\ faculty of Economics, Department of economic theory and world economy \\ Voronezh State Agrarian University named after Emperor Peter the Great \\ Voronezh, Russia \\ elena-falkovich@yandex.ru
}

\begin{abstract}
The article analyzes the essence and contents of the practice of integration, its general methodological principles, summarizes the existing theoretical concepts of international economic integration. The developed foreign theories of integration as a basis for the research rely on the formation of integrated structures as a result of toughening competition in sectoral markets, while domestic economists in their theories rely on the experience of Russian companies that were formed during the first and the second wave of privatization, which confirms the specific nature of the integration processes in Russia.
\end{abstract}

Keywords - integration, concepts of international economic integration.

\section{INTRODUCTION}

The study of the integration practice of business entities involves an analysis of its essence and contents, as well as general methodological principles. In addition, it is important to proceed from the general to the particular, implying the transfer from the level of the global economy to the national economic complex.

In the economic literature, the most developed are the theoretical concepts of international economic integration, which, since the middle of the last century, have reflected the processes taking place in the global economy.

Theories of neoliberalism, neo-Keynesianism, dirigism, structuralism, corporatism and neoliberalism are the most well-known among them.

In the theory of economic integration, a number of branches are distinguished that differ, primarily, in various assessments of the integration mechanism. The analysis of many foreign and domestic theories of economic integration convinces us that there is no single understanding of the essence and goals of economic integration in science.

\section{RESULTS AND DISCUSSION}

The basis of the economic research of the integration was created by the works of the representatives of the classical economic theory (A. Smith, D. Ricardo, J.S. Mill, J.B. Say [8]), who supported the idea of the free trade.

The classical principle of the country's benefit from the specialization of production and exchange of goods based on the international division of labor lay in the base of their approach to foreign trade.

K. Marx and his followers, modern scientific economists such as S. Harris, E. Heckscher, B. Olin, P. Samuelson [9], $\mathrm{V}$. Leontyev and others, considered the economic integration from the point of view of two opposing trends: regionalism and globalization. In the framework of Marxist theory, this concept was defined as the organizational form of imperialism, and its development beyond the national borders is viewed as a manifestation of the convergence of the national production processes and the desire for state-monopoly expansionism.

Before the intensification of integration processes, K. Marx and F. Engels [[5]; [6]] noted the key regularity of the internationalization of economic life due to the development of the processes of initial capital accumulation, geographical discoveries, growth in labor productivity, trade, and also scientific and technological progress.

The representatives of early neoliberalism (1950-1960) Swiss economist V. Repke [[7]] and Frenchman M. Allé [[8]] interpreted the complete integration as the creator of the single market space on a scale of several countries, the functioning of which is based on the action of spontaneous market forces and free competition, regardless of the economic policies of states and existing national and international legal acts.

The intervention of the state in the sphere of international economic relations, in their opinion, leads to such negative phenomena as inflation, the imbalance of international trade, and the disruption of payments.

M. Allé, in his writings, made an attempt “... of a technical presentation of maximum efficiency, where the analysis was subjected to the satisfaction of the needs with the given resources and technical knowledge. At the same time, he considered economic integration as a way of similar development of national economy." [[1]]

Among the four fundamental conclusions formulated by M. Allé, the most significant is that " ... complete liberalization of the trade and the movement of capital is possible and desirable only within the framework of regional complexes combining economically and politically associated countries with a comparable level of economic and social development" [1]. 
However, the development of the international economic integration, the formation of regional interstate unions with the active participation of states showed the failure of the views of the early neoliberals, because, opposing globalization, they did not consider the objective processes of internationalization of economic life.

The representative of late neoliberalism, the Hungarian scholar Bela Balassa, considered the problem of integration in a slightly different way and asked whether economic integration leads to more intensive state participation in economic affairs. Much attention was paid to the evolution of integration taking place on the basis of both economic and political processes.

B. Balassa considered integration both as a process and as a state. "Being considered as a process, it includes measures designed to eliminate discrimination between economic units belonging to different national states; considered as a state, it can be represented as the absence of various forms of discrimination between national economies" [5].

In the theory of economic integration, attention has always focused on developing the concept of creating a joint market. Some of the theorists of economic integration took theories of international trade as the theoretical basis, others included in their concepts movement of capital, services, and labor (M. Alle, M. Halperin, T. Szitowski). They saw the main integration mechanism in the free competition of market forces between independent companies competing with each other. At the same time, they did not pay attention to the regulatory role of the state, and if they considered the role of the state, it was only to show that it should not interfere in foreign economic relations.

In the mid 1960's the direction of corporatism arose, the representatives of which, such as American economists S. Rolf and J. Rostow, identified the new core of integration. They believed that, in contrast to the market mechanism and state regulation, the functioning of TNCs can ensure the integration of the international economy, its rational and balanced development.

The representatives of structuralism, the Swedish economist G. Myrdal [[8]] and others criticized the idea of complete liberalization of the movement of goods, capital, and labor in an integrated space, believing that the free functioning of the market mechanism can lead to certain imbalances in development and distribution of production, deepening income inequality. They considered the economic integration as a deep process of structural transformations in the economies of integrating countries, resulting in a qualitatively new integrated space, a more advanced economic organism. In their opinion, the poles of the development of integration are large firms, industrial companies and entire industries.

In the 1970s the ideas of neo-Keynesianism, whose representatives, the American economist R. Cooper et al., in particular, believed that the central problem of international economic cooperation is how to protect the diverse benefits of wide international economic interaction from restrictions and at the same time maintain maximum degree of freedom for each country.
Neo-Keynesians put forward two possible options for the development of international integration: the first is the integration with the subsequent loss of national freedom, but the mandatory coordination of economic goals and policies; the second is the integration with the condition of preserving as much national autonomy as possible. Assuming that none of these options can be presented in their pure form, they considered it necessary to combine them optimally by coordinating the internal and external economic policies of the integrating parties.

The variation of the neo-Keynesian direction is dirigism, theorists of which also deny the key role of the market mechanism in the integration processes and believe that the creation and functioning of international economic structures is possible on the basis of the development of integrated economic policies by the integrating parties, harmonization of social legislation, and coordination of credit policy. This direction of economic thought is presented by the Dutch scientist J. Tinbergen [[8]], the German scientists R. Sunwald and I. Shtoler.

Institutional theory defines the savings on transaction costs as the main motive for vertical integration, which are divided into monitoring costs for the implementation of exchange operations and information costs. In the framework of this theory, it is substantiated that the increase in transaction costs is an indicator of the life cycle of a vertically integrated company, which is reducing the degree of strength of ties, and replacing other forms of market organization and vertical control [[10]]

To recreate the most holistic picture that gives a systematic idea of neo-institutional theoretical approaches to the study of integration, it is necessary to consider the concept of integration from the point of view of the existence of the three most significant theories: the concept of transaction costs based on the principles of the theory of the company, the theory of the life cycle of the industry, and the concept of strategic advantages.

The concept of transaction costs developed in R.G. Coase [[8], p. 676] and presented in the work "The Nature of the Firm" (1932), proposes that the integration should be scrutinized from the point of view of the tool of substitution of the price mechanism. Coase notes that "... a company will expand until the costs of organizing one additional transaction within the company are equal to the costs of carrying out the same transaction through an exchange on the open market or the costs of organizing it with the help of another company" [[4]].

The fundamental contribution of R.G. Coase's theory of integration should be considered the introduction into the scientific use of the category of transaction costs as "the cost of using the price mechanism, the cost of negotiating and concluding a contract for each exchange transaction" [[4]], as well as the cost of finding the information about real market conditions.

The conceptual foundations of this theory were expanded in the works of Benjamin Klein, Robert J. Crawford, Armen A. Alcian, Oliver I. Williamson. 
Thus, O. Williamson [[7]] considers the integration from the point of view of the mechanism that helps reduce the inefficiency of the imperfect competition markets. In his work "Vertical integration of production: considerations of market failures" [15], he substantiates the advantages of vertical integration over long-term contracts, which are based on the supply of technically complex products with periodically changing designs in accordance with the changes in the market.

"The main idea that defines the essence of the transactional approach to the problem of vertical integration is that integration should be selective. Unlike the claims that are sometimes encountered", the author believes, "that the higher degree of integration is not always the best solution ..." [[7]].

O. Williamson justifies the need for vertical integration by simplifying the solution of industrial conflicts in the production and supply of technically complex products with periodically changing technical parameters.

The additional incentive for vertical integration is the desire to avoid the "risk of irresponsible behavior" on the part of one of the counterparties to the transaction. In this case, the conflicts will be resolved through the use of an administrative mechanism, which is impossible under the contractual nature of the relationship and will require the resolution of differences in court.

The theoretical provisions from O.I. Williamson about the dominance of particular conditions of expediency of using the vertical integration in imperfect competition markets to replace an ineffective market mechanism allows concluding that in an imperfect competition market the value of transaction costs can determine the degree of inefficiency of the market mechanism and justify the implementation of vertical integration while increasing the degree of deviation from market mechanisms of perfect competition.

Implementing the theoretical concepts of $\mathrm{R}$. Coase and O. Williamson, B. Klein, A. Alchian, and R. Crawford develop the concept of opportunistic behavior of producers in the conditions of possession of specialized assets [[1]].

In the work "Vertical Integration, Assigned Annuity, and the Competitive Contracting Process," these authors suggested that "... as assets become more specific and more assignable quasi rent is being created (and, as a result, the potential for gain from opportunistic behavior increases), the cost of making contracts usually will be higher than the cost of vertical integration. Consequently, vertical integration is more preferable" [[1]].

Moreover, vertical integration, from the point of view of the authors, is "a way to save costs in order to avoid the risks of appropriating quasi-rents from specialized assets by opportunistically minded individuals" [[1]].

The vertical integration will help reduce production costs, and the factor in reducing transaction costs will be the increasing competition based on the increased business activity, the speed of information transfer and penetration of foreign manufacturers into the national markets.
The theory of the life cycle of the industry market, developed by J. Stigler [9, [11]], D. Levy, and S. Dezhu, reveals the conditions of the market competition, which contribute to the collapse of vertically integrated chains. These economists are the authors of the concept of the emergence of vertically integrated companies in the initial and final phases of the life cycle of the goods market.

According to their theory, in the intermediate phases of the life cycle of the commodity market (growth and maturity), incentives for vertically integrated relationships are weakened, and their activation is observed when the decline phase begins.

The above conceptual theories do not reveal the contradictions of economic and strategic motives for integration. These aspects are reflected in the works of Salant, Davidson, Deneker, which were based on the use of game theory.

A significant contribution to the theory of economic integration was made by Russian scientists, such as M.M. Maximova, N.P. Shmelev, Yu.V. Shishkov and others. In particular, M.M. Maksimova noted that the appearance of integration complexes represents a higher level (a new qualitative level) of the internationalization of production and economic life.

N.P. Shmelev connects the origins of the global integration processes with the needs of the modern international division of labor, the development of scientific and technological progress, and the deepening of international specialization and cooperation of economic structures of individual countries. He considers the most important characteristics of integration to be the interstate regulation of economic processes, the gradual formation of the integration economic complex with the general proportions and the general structure of reproduction; the removal of administrative and economic barriers for the free movement of goods, capital, and labor within the region; alignment of levels of the economic development of integrating countries.

Yu.V. Shishkov singles out "private integration" of production, national, commodity, and credit markets in the interstate integration process. In his opinion, in the reproduction cycle, the production sphere is least amenable to integration while the credit and financial sphere are much more prone to it. He rightly believes that integration is based on the action of market mechanisms that regulate primarily the direct international economic relations at the level of economic agents. This is naturally followed by the mutual adaptation of national, legal, fiscal, and other systems.

Recently, a number of Russian economist researchers have appeared who consider the institutional economic theory. Among them the following ones should be distinguished: R. Kapelyushnikov, A. Oleinikov, O.V. Inshakova, D.S. Lvov, G.B. Kleiner, V.M. Polterovich.

Three scientific views on the integration can also be distinguished: 1) the concept of market integration; 2) the concept of "controlled integration"; 3) the concept of compromise. 
The representatives of the first concept are B. Belass, G. Kremer, M. Bijet, T. Szitowski, B. Olin. According to the views of these scientists, the essence of the integration is the liberalization of economic exchange between countries, the removal of national barriers in order to create a common market and ensure complete freedom of competition. Only "market integration", in their opinion, can give an economic effect to the integrating nations.

The second concept - the concept of "managed integration" was put forward by S. Ya. Tinberg, A. Philip and J. Pinder. It is based on the active intervention of integration bodies in the sphere of international economic relations and the internal economic development of integrating countries. The scientists conclude the inevitability of creating an economic and then a political union of states endowed with supranational powers.

The representatives of the third concept - the concept of compromises - are X. Wallace, E. Haas and others. They see integration as a process of building various coalitions based on compromises. Such a process, in their opinion, is developing in the field of economics, politics and social relations and automatically leads to the political unification of states within the coalition with all the attributes of the state power.

\section{CONCLUSION}

In general, it is necessary to note that the developed foreign theories of integration as a basis for the research rely on the formation of integrated structures as a result of toughening competition in sectoral markets, while domestic economists in their theories rely on the experience of Russian companies that were formed during the first and the second wave of privatization, which confirms the specific nature of the integration processes in Russia.

Summarizing the studied experience of the existing theoretical approaches to the issue of integration, we can conclude that the main differences between these theories are associated with the different combination of market principles and measures of state influence in the process of economic and political unification of countries, the international division of labor, the establishment of strong economic ties up to formation of large regional systems.

\section{References}

[1] M. Allé, Efficiency conditions in the economy. Moscow: Sci. for the society, 1998, 304 p.

[2] B. Klein, R.G. Crawford, A.A. Alchian, Vertical Integration, Assigned Annuity, and the Competitive Contracting Process, Economics milestones, Vol. 5. Sectoral market theory, ed. by A.G. Slutskiy. St. Petersburg: Econ. school, 2003, 397 p.

[3] B. Klein, R. Crawford, A. Alchian, "Vertical Integration, Appropriable Rent, and Competitive Contracting Process", J. of Law and Econ., no. 6 , 1990.

[4] E. Clair, Global economy: laws of development. Moscow: Thought, 1979, $235 \mathrm{p}$.

[5] R.G. Coase, The Nature of the Firm, Economics milestones, Vol. 2. Company theory, ed. by V.M. Galperin. St. Petersburg: Econ. school, 1999, $360 \mathrm{p}$

[6] K. Marx, F. Engels, Writings, Marx - Engels - Lenin institute at CC AUCP(b), ed. by V. Adoratskiy. Moscow: Partizdat, 1929, 703 p.

[7] World's economic thought. Through the prism of centuries, In 5 volumes, vol. II, Raising capitalism, Exec. ed. M.G. Pokidchenko. Moscow: Thought, 2005, $751 \mathrm{p}$.

[8] World's economic thought. Through the prism of centuries, In 5 volumes, vol. IV, Era of global transformations, Exec. ed. Yu.Ya. Olsevich. Moscow: Thought, 2004, 942 p.

[9] World's economic thought. Through the prism of centuries, In 5 volumes, vol. V, In 2 books, Workdwide honors: Lectures of the Nobel laureats, Exec. ed. G.G. Fetisov, Book 1. Moscow: Thought, 2004, 767 p.

[10] World's economic thought. Through the prism of centuries, In 5 volumes, vol. V, In 2 books, Workdwide honors: Lectures of the Nobel laureats, Exec. ed. G.G. Fetisov, Book 2. Moscow: Thought, 2005, 813 p.

[11] M. Maksimova, "On the issue of national integration theory", World econ. and internat. relat., 6, pp. 104-113, 2007.

[12] J.J. Stigler, Perfect competition: historic angle, Economics milestones, Vol. 2, Company theory, ed. by V.M. Galperin. St. Petersburg: Econ. school, 1999, $360 \mathrm{p}$.

[13] K.S. Ternovykh, N.G. Nechaev, "Development pf the integrated structures of AIC: problems and the stages of solution", Econ. of agricult. and proc. companies, no. 8, pp. 53-57, 2012.

[14] A. Trubilin, V. Sidorenko, P. Mikhaylushkin, "The Priorities of the agrarian policy in Russia”, Int. agricult. J., no. 5, pp. 10-16, 2012.

[15] O.I. Williamson, Vertical integration of production: reflections about the market failures, Economics milestones, vol. 2, Company theory, ed. by V.M. Galperin. St. Petersburg: Econ. school, 1999, 360 p. 